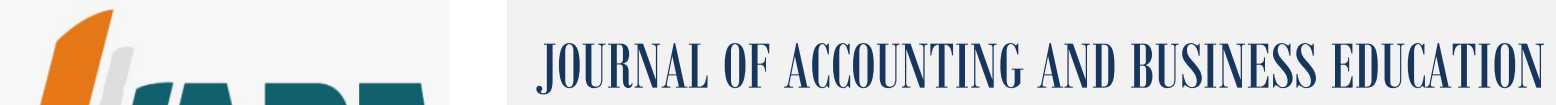 \\ P-ISSN 2520-7281 E-ISSN 2520-729X \\ E-mail: jabe.journal@um.ac.id \\ http://journal.um.ac.id/index.php/jabe/
}

\section{Motivation as Moderating Variable on the Effect of Moral Reasoning and Ethical Sensitivity Toward the Ethical Behavior of Accounting Students}

\author{
Sigit Hermawan \\ Lilin Nur Indah Sari \\ Universitas Muhammadiyah Sidoarjo \\ Email : sigithermawan@umsida.ac.id
}

\begin{abstract}
This research aims to prove the effect of moral reasoning and ethical sensitivity on accounting students' ethical behavior on the basis of motivation as moderating variables. Respondents on this research were accounting students of Universitas Muhammadiyah Sidoarjo. The data was collected by using questionnaire method. 131 questionnaires were distributed and analyzed. This research used multiple linear regression analysis and moderated regression analysis (MRA). On other side, this research was helped by SPSS (Statistical Package for Social Scienci) versi 18.0 software. The result of this research showed that Moral Reasoning and Ethical Sensitivity affects partially to the ethical behavior of accounting students. Meanwhile, motivation was able to moderate the effect of Moral Reasoning and Ethical Sensitivity to the ethical behavior of accounting students.
\end{abstract}

Keywords: Moral reasoning, ethical sensitivity, ethical behavior, motivation, behaviour accounting

\section{INTRODUCTION}

Public pressure to take action and ethical behavior on many companies and businesses is increasing. Corporate scandals such as Enron, Worldcom, Adelphia and Sarbanes Oxley Act (SOX) are examples of unethical business practices (Haron et al, 2015). As a result of the companies' scandal many economic structures were damaged. Therefore, public demand the ethical business practices.

Ethical behavior is very important in relation to ethical actions. It will lead to the ethical and law violation if it is violated. Ethical behavior of a person cannot be separated from moral reasoning. According to Gaffikin and Lindawati (2012), moral reasoning defined as an argument about how a person must act or provide an excuse to justify and criticize an action. If a student who has low moral reasoning, he tends to behave differently with students who have high moral reasoning . Research conducted by Al-Fithrie (2015) proved that moral reasoning has a positive 
and significant effect on the ethical perception of accounting students. Research conducted on auditors in Malaysia also produces the same thing that moral reasoning influences ethical judgment in Malaysia (Haron et al, 2015).

Another thing that draw an attention related to ethical behavior and morality is ethical sensitivity. Ethical sensitivity is a basic element of human moral behavior. Ethical sensitivity is more technically stated as identification of aspects that in certain situations involve good and bad behavior from someone (Shamsuddin et al, 2015). Thus ethical sensitivity will influence a person's ethical behavior.

Ethical sensitivity in higher education differs between students and it is defined as the ability to realize that taking decisions should be on norms, ethical and moral values. Research conducted by Yovita and Rahmawaty (2016) which proves that ethical sensitivity affects the ethical behavior of accounting students of Syiah Kuala University. There are similarities between the present study and previous study namely, both of them use the ethical sensitivity variable and ethical behavior of accounting students. However, in this present study, the moral reasoning variable is added.

Based on two variables that have been discussed, moral reasoning and ethical sensitivity, there are other variables that strengthen and weaken the relationship of the students' ethical behavior, namely motivation. Motivation itself is defined as the desire contained in an individual that stimulates them to take actions (Hasibuan, 2006: 145). Ethical behavior possessed by each student is different and influenced by moral reasoning and ethical sensitivity. This shows that if moral reasoning and ethical sensitivity are low, then students tend not to commit actions that cause violations. Conversely, if moral reasoning and ethical sensitivity are high, then students tend to carry out actions that cause ethical violations.

Likewise, the students who have high motivation will have a high level of moral reasoning and ethical sensitivity. In addition, students who have low motivation will have a low level of moral reasoning and ethical sensitivity. The students only rely on logic without thinking with feelings. Thus the ethical behavior of each student is different, this is because motivation is able to strengthen or weaken the relationship between moral reasoning and ethical sensitivity.

This research is different from Al Fitrie's (2015) research. The difference lies in the moderating variables. Al Fitrie's research (2015) used gender as moderating variable while this research used motivation. This research is also different from the research of Yovita and 
Rahmawaty (2016) which used gender variables and locus of control as independent variables and did not use moderating variables. Similarly, Febrianty (2010) research did not use moral reasoning and did not use motivational as moderating variables. By paying attention to the differences in this study with previous research it will be very interesting to examine the research that includes motivation as a moderating variable with moral reasoning and ethical sensitivity as independent variables and ethical behavior of accounting students as the dependent variable. Thus the purpose of this study was to analyze motivation as a moderating variable on the effect of moral reasoning and ethical sensitivity on the ethical behavior of accounting students.

\section{LITERATURE REVIEW AND HYPOTHESES}

The basic theories relevant to this research are attribution theory and teleology theory. Attribution theory is developed by Fritz Heider which states that a person's behavior is determined by a combination of internal forces, namely the factors that come from within a person, such as ability or effort and external forces, namely factors those from outside, such as difficulties in work or luck (Lubis, 2014). This theory has an important role in understanding the behavior of others. Such behavior can be seen by the distinctiveness, consistency and consensus.Distinctiveness is the degree to which a person can behave the same in different situations. Consistency is a level which a person can show the same behavior at different times. Consensus is a level which other people show the same behavior. This theory is to motivate someone to behave according to the situation he is facing. The relationship between attribution theory and this research is the action taken by each individual that is caused by the existence of the attribution theory.

Meanwhile, teleology theory is also very relevant when it is associated with behavioral and ethical research themes. This theory consists of ethical and utilitarianism egoism. Ethical egoism is an action based on oneself-interest. This behavior is only thinking of oneself without caring for others. Utilitarianism is an act that can be said to be good if it brings benefits to as many community members as possible, or with the very well-known term "The greatest happiness of the greatest numbers". In this behavior, something can be said to be ethical if it provides benefits to a group of people or a group of people (Agoes and Ardana, 2009). Thus the relationship between the theory of teleology and this research is to find out the changes in one's behavior in making a decision. 
Furthermore Brooks and Dunn (2011) identify ethical behavior as an indication of mens rea, which is one of two dimensions of responsibility, the possibility of making mistakes, or feeling guilty. In many ways, discussions about ethical behavior are inseparable from discussions about ethics and morals. Ethics is a branch of philosophy that investigates normative assessment of whether this action is right or what should be done (Brooks and Dunn, 2011).

Another behavior discussed in this study is moral behavior. According to Agoes and Ardana (2009), moral behavior is a behavior that follows the moral codes of certain community groups. Moral in this case means customs or traditions. Immoral behavior means behavior that fails to comply with the expectations of the social group. Behavior outside moral awareness is a behavior that deviates from the expectations of social groups which is more due to the inability of the concerned in understanding the expectations of social groups. Gaffikin and Lindawati (2012), stated that moral behavior depends on four things, they are the prospect of punishment and individual desires, social norms and the rights of others, punishment and respond to duty obligations (in the sense of deontology), orientation of social contracts such as, equality and human dignity, and also respecting universal principles such as values, truth, honor and integrity (in policy theory).

Moral behavior cannot be separated from human ethical behavior. Furthermore, ethical behavior will always be associated with ethical sensitivity. According to Brooks and Dunn (2011: 5) during the period of the 1980s and 1990s, there was a significant increase in sensitivity due to a lack of honesty and differences in fair treatment for individuals and groups in society. The ability to realize the existence of ethical or moral values in taking a decision is called ethical sensitivity (Irawan, 2011). According to Al-Fithrie (2015) states that ethical sensitivity has an important role for individuals in measuring the level of sensitivity to norms, ethical and moral values within and outside environment.

Based on the behaviors discussed above, the action that based on morality and ethic depends on the motivation of the person. Related to motivation, Mangkunegara (2005) defines motivation as a condition or energy that moves in an individual that is directed towards achieving organizational goals. Motivation is something that arises from within a person to achieve the goals he wants (Lubis, 2014). GR Terry suggested that motivation is a desire that is found in an individual who stimulates them to take actions (Hasibuan, 2006). Motivation is influenced by two impulses, encouragement from within yourself and encouragement from 
outside yourself or other parties (Mangkunegara, 2005). Motivation in humans is motivated by: 1) the desire for life, 2) the desire to have something, 3) the desire for power, and 4) the desire for recognition (Lubis, 2014). Motivation is a process that begins with psychological deficiencies that drive behaviors that are aimed at certain incentives (Luthans, 2006: 270).

Meanwhile, several studies link moral behavior or moral reasoning with ethical behavior. One research is Al-Fithrie (2015) which states that moral reasoning has a positive and significant effect on the ethical perception of accounting students. This is because moral behavior is a behavior that follows the moral code of certain community groups. Moral in this case means customs or traditions. Immoral behavior means behavior that fails to comply with the expectations of the social group. To avoid immoral behavior a person must understand the problem at hand before making a decision. When accounting students are faced with various cases of ethical violations committed by an accountant, accounting students must have an ethical attitude in dealing with the case. If accounting students have a high level of moral reasoning in ethical behavior, then they tend to do good deeds. Meanwhile, if accounting students have a low level of moral reasoning in ethical behavior, then they tends to do actions that are not in accordance with moral principles.

Furthermore, the relationship between ethical sensitivity and ethical behavior is shown by the results of Febrianty's research (2010) which states that ethical sensitivity variable have a positive and significant effect on the ethical behavior of accounting students. This is because ethical sensitivity is very important to be owned by each individual to measure the level of sensitivity to existing values both inside and outside environment (Al-Fithrie, 2015). Accounting students should have high ethical sensitivity so that the possibility of ethical violations is very low. If accounting students have low ethical sensitivity, they will tend to conduct high unethical actions that cause ethical violations.

Moral reasoning and ethical sensitivity can also be related to ethical behavior. Since a person or student who has a high level of moral reasoning and ethical sensitivity tends to behave ethically, while students who have low levels of moral reasoning and ethical sensitivity tend to behave unethically. Like the results of research by Yovita and Rahmawaty (2016) which states that gender, ethical sensitivity, understanding the code of ethics of the accounting profession, and locus of control have a positive and significant effect simultaneously on the ethical behavior of accounting students of Syiah Kuala University. 
In the aforementioned explanation, it is stated that motivation can be a determining variable of behavior and morals. Since motivation is a function of various variables that influence each other (Indrawijaya, 2002). The level of moral reasoning that is possessed by each student is influenced by motivation. Students who have high motivation tend to have a high level of moral reasoning because students are motivated to do good. Conversely, students who have low motivation tend to have low levels of moral reasoning because there is no motivation to do good. Therefore, motivation produces a high or low level of moral reasoning and can affect the ethical behavior of accounting students. Based on the description above, motivation can be a moderating variable in the influence of moral reasoning on the Ethical Behavior of Accounting Students.

Furthermore, the level of ethical sensitivity possessed by each student is influenced by motivation. Students who have high motivation tend to have a high level of ethical sensitivity because these students use feelings in thinking and doing activities more. Conversely, students who have low motivation tend to have a low level of ethical sensitivity because these students use logic in thinking and doing activities. Therefore, motivation produces a high or low level of moral reasoning and can affect the ethical behavior of accounting students. Based on the description, motivation can be a moderating variable moderating in the influence of ethical sensitivity on the ethical behavior of accounting students.

Therefore the conceptual frame of this study is :

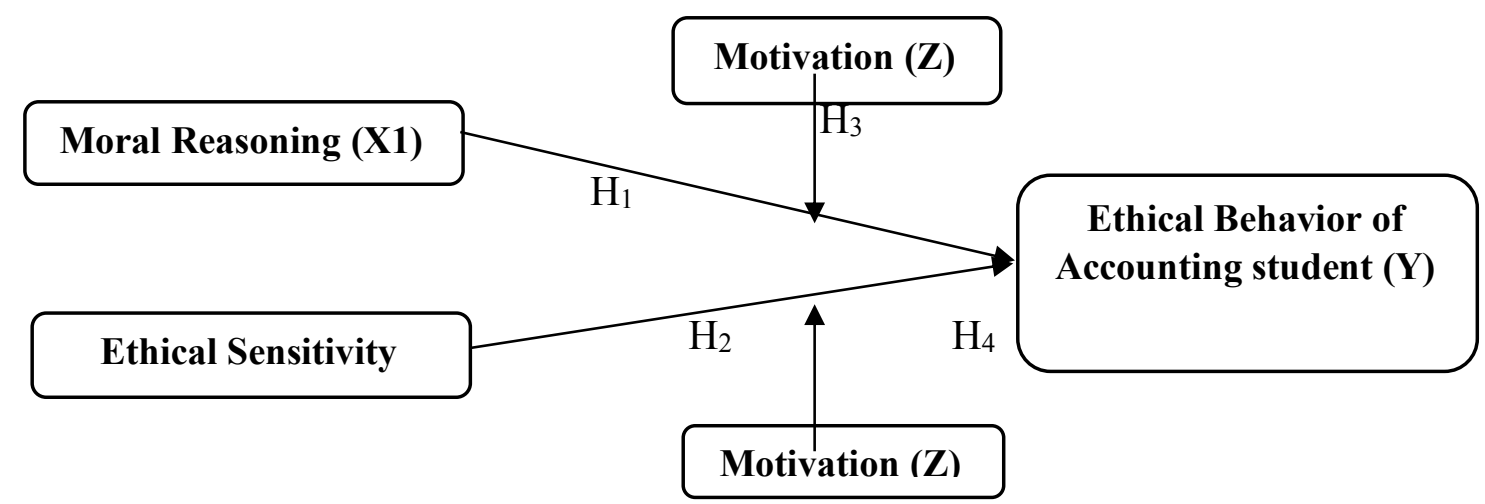

Information:

: Partial

: Simultaneous

The hypothesis of this study are : 
H1. Moral Reasoning Affects the Ethical Behavior of Accounting Students

H2. Ethical Sensitivity Affects the Ethical Behavior of Accounting Students

H3. Motivation Moderates the Effect of Moral Reasoning to the Ethical Behavior

H4. Motivation Moderates the Effect of Ethical Sensitivity to the Ethical Behavior

\section{METHODS}

The research was causal research that connects between independent and dependent variables or causal variables (Hermawan and Amirullah, 2016). In this study there were two independent variables (moral reasoning and ethical sensitivity), one dependent variable (ethical behavior of accounting students), and one moderating variable (motivation). Based on the operational definitions of the relevant variables and literature reviews, the following variable indicators are presented.

Tabel 1

Operational Definition and Variable Measurement

\begin{tabular}{|c|c|c|c|c|}
\hline Variable & Concept & Indicator & Scale & Source \\
\hline $\begin{array}{l}\text { Moral } \\
\text { Reasoning } \\
\quad \text { (X1) }\end{array}$ & $\begin{array}{l}\text { Moral Reasoning is defined } \\
\text { as an argument about how } \\
\text { a person must act or } \\
\text { provide an excuse to } \\
\text { justify and criticize an } \\
\text { action (Gaffikin and } \\
\text { Lindawati, 2012). }\end{array}$ & $\begin{array}{l}\text { a) Justice atau Moral } \\
\text { Equity } \\
\text { b) Relativism } \\
\text { c) Egoism } \\
\text { d) Unilitariansm } \\
\text { Deontologi atau } \\
\text { Contractual } \\
\end{array}$ & $\begin{array}{l}\text { Likert, } \\
\text { Skala } 5\end{array}$ & $\begin{array}{l}\text { a) Januarti } \\
\text { dan Faisal } \\
(2010) \\
\text { b) Al-Fithrie } \\
\text { (2015) }\end{array}$ \\
\hline $\begin{array}{l}\text { Ethical } \\
\text { Sensitivity } \\
\quad \text { (X2) }\end{array}$ & $\begin{array}{l}\text { Ethical sensitivity is the } \\
\text { ability to be aware of } \\
\text { ethical or moral values in a } \\
\text { decision (Irawan, 2011). }\end{array}$ & $\begin{array}{l}\text { a) Cheating during } \\
\text { examination } \\
\text { b) Group / Individual } \\
\text { Task. }\end{array}$ & $\begin{array}{l}\text { Likert, } \\
\text { Skala } 5\end{array}$ & $\begin{array}{l}\text { a) Wibowo } \\
(2002) \\
\text { b) Risa } \\
(2011) \\
\text { c) Fitri } \\
(2015)\end{array}$ \\
\hline $\begin{array}{l}\text { Ethical } \\
\text { Behavior } \\
\quad(Y)\end{array}$ & $\begin{array}{l}\text { Ethical behavior identified } \\
\text { as indicative of mens rea } \\
\text { (guilty thoughts), which is } \\
\text { one of two dimensions of } \\
\text { responsibility, the } \\
\text { possibility of making } \\
\text { mistakes, or feelings of } \\
\text { guilt (Brooks and Dunn, } \\
2011: 255) \text {. }\end{array}$ & $\begin{array}{l}\text { a) Understanding and } \\
\text { Recognizing the } \\
\text { behavior based on ethic } \\
\text { code. } \\
\text { b) Doing consistence } \\
\text { behavior by the value } \\
\text { and believe } \\
\text { c) Doing based on the } \\
\text { value. } \\
\text { d) Doing based on the }\end{array}$ & $\begin{array}{l}\text { Likert, } \\
\text { Skala } 5\end{array}$ & $\begin{array}{l}\text { a) Rachman } \\
\text { (2006) } \\
\text { b) Pamela } \\
\text { (2014) }\end{array}$ \\
\hline
\end{tabular}




\begin{tabular}{|c|c|c|c|c|c|}
\hline & & $\begin{array}{l}\text { value even if it causes } \\
\text { risk. }\end{array}$ & & & \\
\hline $\begin{array}{l}\text { Motivation } \\
\text { (Z) }\end{array}$ & $\begin{array}{l}\text { GR Terry suggests that } \\
\text { motivation is a desire that } \\
\text { is found in an individual } \\
\text { who stimulates him to take } \\
\text { actions (Hasibuan, 2006: } \\
\text { 125). }\end{array}$ & $\begin{array}{l}\text { a) Having a high level of } \\
\text { personal responsibility. } \\
\text { b) Dare to take and carry } \\
\text { the risk. } \\
\text { c) Have realistic goals. } \\
\text { d) Having a comprehensive } \\
\text { work plan and striving } \\
\text { to realize the goals. } \\
\text { e) Utilizing concrete } \\
\text { feedback in all activities } \\
\text { carried out. } \\
\text { f) Look for opportunities to } \\
\text { realize plans that have } \\
\text { been programmed. }\end{array}$ & $\begin{array}{l}\text { Likert, } \\
\text { Skala } 5\end{array}$ & b) & $\begin{array}{l}\text { Mangkun } \\
\text { egara } \\
(2005) \\
\text { Nisa } \\
(2016)\end{array}$ \\
\hline
\end{tabular}

The population of this study were eighth semester students of the accounting study program of the Faculty of Economics and Business, Muhammadiyah University of Sidoarjo (FEB Umsida). The reason for choosing eighth semester students is because students have taken behavioral accounting courses and business and professional ethics. According to the Academic Administration Bureau (BAA - UMSIDA, 2017) the student data of the eighth or 2013 accounting semester study program was 131 students. For the sample of this study using saturated samples or if all the population is used as a sample (Sugiyono, 2014).

The data collection done by distributing questionnaires to respondents who have been determined at the beginning. For the distribution of questionnaires using stratified random sampling because of the different amounts for each class in the FEB Umsida Accounting Study Program. The method used is by going directly to the respondents, explaining the purpose of the questionnaire and giving the questionnaire to the respondent. Furthermore, for data analysis is carried out by stages, namely the test of validity and reliability, hypothesis testing with multiple linear regression analysis, and analysis of moderated regression analysis (MRA) (Ghozali, 2005).

\section{RESULTS}

Based on a predetermined research design, the researcher then distributed questionnaires to 131 respondents. All the questionnaires were returned and analyzed. Based on the returned questionnaire data, the following are the characteristics of respondents. 
Table 2

Characteristic of Respondents by Age

\begin{tabular}{|c|c|c|c|c|}
\hline & Frequency & Percent & $\begin{array}{c}\text { Valid } \\
\text { Percent }\end{array}$ & $\begin{array}{c}\text { Cumulative } \\
\text { Percent }\end{array}$ \\
\hline Valid 20-23 Year & 117 & 89,3 & 89,3 & 89,3 \\
24-27 Year & 13 & 9,9 & 9,9 & 99,2 \\
>27 Year & 1 &, 8 &, 8 & 100,0 \\
Total & 131 & 100,0 & 100,0 & 100,0 \\
\hline
\end{tabular}

Source: Data processed using SPSS 18

Based on Table 2 above, it was known that respondents with the ages of 20-23 years were 117 respondents with a percentage of $89.3 \%$. The age of $24-27$ years was 13 respondents with a percentage of $9.9 \%$. The Age of more than 27 years was 1 with a percentage of $0.8 \%$. These results indicated that more respondents were at the age of 20-23 years with as many as 117 respondents or equal to $89.3 \%$.

Characteristics of respondents based on gender can be seen in Table 3 below:

Table 3

Characteristic of Respondents by Gender

\begin{tabular}{|c|c|c|c|c|c|}
\hline & & Frequency & Percent & $\begin{array}{c}\text { Valid } \\
\text { Percent }\end{array}$ & $\begin{array}{c}\text { Cumulative } \\
\text { Percent }\end{array}$ \\
\hline \multirow[t]{3}{*}{ Valid } & Male & 28 & 21,4 & 21,4 & 21,4 \\
\hline & Female & 103 & 78,6 & 78,6 & 100,0 \\
\hline & Total & 131 & 100,0 & 100,0 & \\
\hline
\end{tabular}

Source: Data processed using SPSS 18

Based on Table 3 above, it was known that male respondents were 28 people with the percentage of $21.4 \%$ while Female respondents were 103 respondents with the percentage of $78.6 \%$. This shows that there were more female respondents than male respondents in this study.

\section{Validity Test}

The next step after describing the characteristics of respondents was the validity test and reliability test. Validity is a measure that shows the validity level of a measuring instrument. In 
this study the validity test of instrument items was known by comparing the corrected item-total correlation obtained or $\mathrm{r}$ count with 0.30 (cronbach alpha). If $\mathrm{r}$ count is more bigger than 0.30 (cronbach alpha), the question item is declared valid. The results of the validity test for variables moral reasoning $(\mathrm{X} 1)$ were as follows:

Table 4

Validity Test for Moral Reasoning $\left(\mathrm{X}_{1}\right)$

\begin{tabular}{|c|c|c|c|c|}
\hline $\begin{array}{c}\text { Number of } \\
\text { Questions }\end{array}$ & $\begin{array}{c}\text { Questions } \\
\text { Code }\end{array}$ & $\begin{array}{c}\text { Corrected item- } \\
\text { Total } \\
\text { Correlation }\end{array}$ & Constrac & Information \\
\hline 1 & X1_1 & 0,859 & 0,3 & Valid \\
\hline 2 & X1_2 & 0,879 & 0,3 & Valid \\
\hline 3 & X1_3 & 0,836 & 0,3 & Valid \\
\hline 4 & X1_4 & 0,872 & 0,3 & Valid \\
\hline 5 & X1_5 & 0,833 & 0,3 & Valid \\
\hline 6 & X1_6 & 0,855 & 0,3 & Valid \\
\hline 7 & X1_7 & 0,817 & 0,3 & Valid \\
\hline
\end{tabular}

Source : Data processed using SPSS 18

Based on the calculation of the validity test on the variable $\mathrm{X}_{1}$ (moral reasoning), showed that the entire the questionnaire items were all valid. This was proven by the corrected item-total correlation value was greater than the value of cronbach alpha (0.3). (Sugiyono, 2014).

Next is the result of the validity test for variable $\mathrm{X}_{2}$ (ethical sensitivity), as follows:

Table 5

Validity Test for Ethical sensitivity $\left(\mathrm{X}_{2}\right)$

\begin{tabular}{|c|c|c|c|c|}
\hline $\begin{array}{c}\text { Number of } \\
\text { Questions }\end{array}$ & $\begin{array}{c}\text { Question } \\
\text { Code }\end{array}$ & $\begin{array}{c}\text { Corrected item- } \\
\text { Total } \\
\text { Correlation }\end{array}$ & Constrac & Information \\
\hline 1 & X2_1 & 0,806 & 0,3 & Valid \\
\hline 2 & X2_2 & 0,831 & 0,3 & Valid \\
\hline 3 & X2_3 & 0,829 & 0,3 & Valid \\
\hline 4 & X2_4 & 0,800 & 0,3 & Valid \\
\hline
\end{tabular}




\begin{tabular}{|l|l|l|l|l|}
\hline 5 & $\mathrm{X} 2 \_5$ & 0,811 & 0,3 & Valid \\
\hline 6 & $\mathrm{X} 2 \_6$ & 0,532 & 0,3 & Valid \\
\hline
\end{tabular}

Source : Data processed using SPSS 18

Based on the calculation of the validity test of the variable $\mathrm{X}_{2}$ (ethical sensitivity), it indicated that all questionnaires were valid. This was proven by the corrected item-total correlation value was greater than the value of cronbach alpha (0.3). (Sugiyono, 2014).

Next is the result of the validity test for the variable $\mathrm{Z}$ (motivation), as follows:

Table 6

Validity Test for (Z) Motivation

\begin{tabular}{|c|c|c|c|c|}
\hline $\begin{array}{c}\text { Number of } \\
\text { Questions }\end{array}$ & $\begin{array}{c}\text { Questions } \\
\text { Code }\end{array}$ & $\begin{array}{c}\text { Corrected item- } \\
\text { Total } \\
\text { Correlation }\end{array}$ & Constrac & Information \\
\hline 1 & Z_1 & 0,847 & 0,3 & Valid \\
\hline 2 & Z_2 & 0,901 & 0,3 & Valid \\
\hline 3 & Z_3 & 0,925 & 0,3 & Valid \\
\hline 4 & Z_4 & 0,939 & 0,3 & Valid \\
\hline 5 & Z_5 & 0,901 & 0,3 & Valid \\
\hline 6 & Z_6 & 0,871 & 0,3 & Valid \\
\hline
\end{tabular}

Source : Data processed using SPSS 18

Based on the results of the validity of the $\mathrm{Z}$ variable (motivation), showed that all questionnaires were valid. This was proven by the corrected item-total correlation value was greater than the value of cronbach alpha (0.3). (Sugiyono, 2014).

Next is the result of the validity test for variable Y (ethical behavior of accounting students), as follows:

Table 7

Validity Test for (Y) The Ethical Behavior of Accounting Students

\begin{tabular}{|c|c|c|c|c|}
\hline $\begin{array}{c}\text { Number of } \\
\text { Questions }\end{array}$ & $\begin{array}{c}\text { Question } \\
\text { Code }\end{array}$ & $\begin{array}{c}\text { Corrected item- } \\
\text { Total Correlation }\end{array}$ & Constrac & Information \\
\hline 1 & Y_1 & 0,681 & 0,3 & Valid \\
\hline 2 & Y_2 & 0,793 & 0,3 & Valid \\
\hline
\end{tabular}




\begin{tabular}{|l|l|l|l|l|}
\hline 3 & Y_3 & 0,777 & 0,3 & Valid \\
\hline 4 & Y_4 & 0,525 & 0,3 & Valid \\
\hline
\end{tabular}

Source : Data processed using SPSS 18

Based on the calculation of the validity of the $\mathrm{Y}$ variable (ethical behavior of accounting students), showed that all questionnaires were valid. This was proven by the corrected item-total correlation value was greater than the value cronbach alpha (0.3). (Sugiyono, 2014).

\section{Reliability Test}

A reliable instrument is an instrument that will produce the same data if it is used used several times to measure the same object. In a construct or variable it is said to be reliable if it gives a cronbach's alpha value $>0.60$. Following are the results of reliability testing for each variable.

Table 8

Reliability Test for Moral Reasoning $\left(\mathrm{X}_{1}\right)$

\begin{tabular}{|c|c|c|}
\hline $\begin{array}{c}\text { Cronbach's } \\
\text { Alpha }\end{array}$ & $\begin{array}{c}\text { Cronbach's Alpha Based on } \\
\text { Standardized Items }\end{array}$ & $\begin{array}{c}\text { N of } \\
\text { Items }\end{array}$ \\
\hline, 957 &, 957 & 7 \\
\hline
\end{tabular}

Source : Data processed using SPSS 18

Table 9

Reliability Test for Ethical Sensitivity $\left(\mathrm{X}_{2}\right)$

\begin{tabular}{|c|c|c|}
\hline $\begin{array}{c}\text { Cronbach's } \\
\text { Alpha }\end{array}$ & $\begin{array}{c}\text { Cronbach's Alpha Based on } \\
\text { Standardized Items }\end{array}$ & $\begin{array}{c}\text { N of } \\
\text { Items }\end{array}$ \\
\hline, 917 &, 918 & 6 \\
\hline
\end{tabular}

Source : Data processed using SPSS 18

Table 10

Reliability Test for Motivation (Z)

\begin{tabular}{|c|c|c|}
\hline $\begin{array}{c}\text { Cronbach' } \\
\text { s Alpha }\end{array}$ & $\begin{array}{c}\text { Cronbach's Alpha Based on } \\
\text { Standardized Items }\end{array}$ & N of Items \\
\hline, 968 &, 968 & 6 \\
\hline
\end{tabular}

Source : Data processed using SPSS 18 
Table 11

Reliability Test for Ethical Behavior of Accounting students (Y)

\begin{tabular}{|c|c|c|}
\hline $\begin{array}{c}\text { Cronbach' } \\
\text { s Alpha }\end{array}$ & $\begin{array}{c}\text { Cronbach's Alpha Based on } \\
\text { Standardized Items }\end{array}$ & N of Items \\
\hline, 850 &, 851 & 4 \\
\hline
\end{tabular}

Sumber : Data diolah melalui SPSS versi 18

A variable is said to be reliable if Cronbach alpha is more than 0.6 (Ghozali, 2005). Based on the reliability test results in Tables $8,9,10$, and 11, all showed the value of Cronbach alpha was greater than 0.6 so that all variables were declared reliable.

\section{Hypothesis Test}

\section{Regression Analysis}

Based on the analysis test using SPSS, the regression coefficient test results were obtained in Table 12 below

Table 12

Regression of Coefficient test

\begin{tabular}{|l|c|c|c|c|c|}
\hline \multirow{2}{*}{ Model } & \multicolumn{2}{|c|}{$\begin{array}{c}\text { Unstandardized } \\
\text { Coefficients }\end{array}$} & $\begin{array}{c}\text { Standardized } \\
\text { Coefficients }\end{array}$ & \multirow{2}{*}{ T } & Sig. \\
\cline { 2 - 5 } & B & Std. Error & Beta & 4,204 &, 000 \\
\hline (Constant) & 4,502 & 1,071 &, 201 & 2,359 &, 020 \\
Moral &, 100 &, 042 &, 594 & 6,958 &, 000 \\
Reasoning &, 397 &, 057 & & & \\
Ethical & & & & & \\
Sensitivity & & & & & \\
\hline
\end{tabular}

a. Dependent Variable: Ethical Behavior

Source : Data processed using SPSS 18

Based on Table 12, It can be explained through formula as follows

$$
Y=4,502+0,100 X_{1}+0,397 X_{2}
$$


Table 13

Test Results of Determination Coefficient

\begin{tabular}{|c|c|c|c|c|}
\hline Model & R & R Square & $\begin{array}{c}\text { Adjusted R } \\
\text { Square }\end{array}$ & $\begin{array}{c}\text { Std. Error of } \\
\text { the Estimate }\end{array}$ \\
\hline 1 &, $755 \mathrm{a}$ &, 569 &, 563 & 1,603 \\
\hline
\end{tabular}

a. Predictors: (Constant), Ethical Sensitivity, Moral Reasoning

b. Dependent Variable: Ethical Behavior

Source : Data processed using SPSS 18

Based on the results of the coefficient of determination it can be seen that the coefficient of determination $\mathrm{R}$ square $\left(\mathrm{R}_{2}\right)$ of 0.569 , meant $56.9 \%$ that the variable Moral Reasoning (X1) and Ethical Sensitivity (X2) affected the Ethical Behavior (Y) variable by $56.9 \%$ while the rest (100 $56.9=43,1 \%$ ) was influenced by other variables.

Next presented the results of statistical test data t, MRA hypothesis 3 test results, and MRA hypothesis test results 4 .

Table 14

The result of Statistical t

\begin{tabular}{|l|c|c|c|c|c|}
\hline \multirow{2}{*}{ Model } & \multicolumn{2}{|c|}{$\begin{array}{c}\text { Unstandardized } \\
\text { Coefficients }\end{array}$} & $\begin{array}{c}\text { Standardized } \\
\text { Coefficients }\end{array}$ & \multirow{2}{*}{ T } & Sig. \\
\cline { 2 - 5 } & B & Std. Error & Beta & 4,204 &, 000 \\
\cline { 2 - 4 } (Constant) & 4,502 & 1,071 & & 2,359 &, 020 \\
Moral &, 100 &, 042 &, 201 & & \\
Reasoning &, 397 &, 057 &, 594 & 6,958 &, 000 \\
Ethical & & & & & \\
\hline
\end{tabular}

a. Dependent Variable: Perilaku Etis

Source : Data processed using SPSS 18 
Table 15

The result of MRA Hipotesis 3

\section{Coefficients $^{\mathbf{a}}$}

\begin{tabular}{|c|c|c|c|c|c|}
\hline \multirow[t]{2}{*}{ Model } & \multicolumn{2}{|c|}{$\begin{array}{c}\text { Unstandardized } \\
\text { Coefficients }\end{array}$} & \multirow{2}{*}{\begin{tabular}{|c|}
$\begin{array}{c}\text { Standardized } \\
\text { Coefficients }\end{array}$ \\
Beta
\end{tabular}} & \multirow[b]{2}{*}{$\mathbf{T}$} & \multirow[b]{2}{*}{ Sig. } \\
\hline & B & Std. Error & & & \\
\hline (Constant) & $-15,143$ & 6,227 & & $-2,432$ &, 016 \\
\hline $\begin{array}{l}\text { Moral } \\
\text { Reasoning }\end{array}$ & 1,051 & ,196 & 2,115 & 5,363 &, 000 \\
\hline Motivation & ,915 & ,236 & 1,536 & 3,873 &, 000 \\
\hline Moderating_1 &,- 028 & ,007 & $-2,084$ & $-3,794$ &, 000 \\
\hline
\end{tabular}

a. Dependent Variable: Ethical Behavior

Source : Data processed using SPSS 18

Table 16

The resulf of MRA Hipotesis 4

\begin{tabular}{|l|c|c|c|c|c|}
\hline \multirow{2}{*}{ Model } & \multicolumn{2}{|c|}{$\begin{array}{c}\text { Unstandardized } \\
\text { Coefficients }\end{array}$} & $\begin{array}{r}\text { Standardized } \\
\text { Coefficients }\end{array}$ & & \\
\cline { 2 - 4 } & B & Std. Error & Beta & T & Sig. \\
\hline (Constant) & $-15,680$ & 6,150 & & $-2,550$ &, 012 \\
Ethical & 1,248 &, 222 & 1,866 & 5,624 &, 000 \\
Sensitivity &, 816 &, 241 & 1,370 & 3,390 &, 001 \\
Motivation &,- 030 &, 009 & $-1,835$ & $-3,437$ &, 001 \\
Moderating_2 & & & & \\
\hline
\end{tabular}

a. Dependent Variable: Ethical Behavior

Source : Data processed using SPSS 18

Based on the results of hypothesis testing and MRA tests that have been presented in Tables 14, 15, and 16, the following results were obtained. 
1. Moral Reasoning affected ethical behavior. This can be seen from the results of data analysis which showed that Moral Reasoning was obtained with a significant value of 0.020 smaller than 0.05 or $0.020<0.05$ (see Table 14). Thus H1 was accepted.

2. Ethical Sensitivity affected ethical behavior. This can be seen from the results of data analysis which showed that the Ethical Sensitivity obtained with a significant value of 0,000 less than 0.05 or $0,000<0,05$ (see Table 14). Thus H2 was accepted.

3. Motivation moderated the influence of moral reasoning on ethical behavior. This can be seen from the results of data analysis which showed that a significant value of 0,000 less than 0.05 or $0,000<0.05$ (see Table 15). Thus H3 was accepted.

4. Motivation moderated the effect of ethical sensitivity on ethical behavior. This can be seen from the results of data analysis which showed that a significant value of 0.001 less than 0.05 or $0.001<0.05$ (see Table 16). Thus H4 was accepted

\section{DISCUSSION}

Based on the results of the hypothesis, a discussion is held for each hypothesis.

\section{Moral Reasoning Affects Ethical Behavior}

Based on the results of the hypothesis testing, H1 was accepted, which means that moral reasoning affects ethical behavior. Moral reasoning is defined as an argument about how a person must act or give an excuse to justify and criticize an action. When accounting students are faced with various cases of ethical violations committed by an accountant, accounting students must have an ethical attitude in dealing with the case. If accounting students have a high level of moral reasoning in ethical behavior, then they tend not to do bad deeds. Meanwhile, if accounting students have a low level of moral reasoning in ethical behavior, then it tends to do actions that are not in accordance with moral principles. The results of this study are supported by teleology theory which explains that there is a change in one's behavior in taking an ethical or unethical decision.

The results of this study are also in accordance with the theory of moral reasoning which states that a person must think using sound logic before making a decision. When compared with previous studies, the results of this study support the research of Al-Fithrie (2015) stating that moral reasoning has a positive and significant effect on the ethical perception of accounting students. This research also supports the research of Hermiyetti, et al. (2015) which states that 
moral reasoning and student personal factors simultaneously have a positive and significant effect on the moral behavior of accounting students of the Faculty of Economics, Pancasila University.

\section{Ethical Sensitivity Affects Ethical Behavior}

Based on the results of the hypothesis testing, $\mathrm{H} 2$ is accepted, which means that ethical sensitivity affects ethical behavior. Ethical Sensitivity is the ability of a person to understand ethics in making an ethical decision. Ethical sensitivity is very important for each individual to measure the level of sensitivity to values that exist within and outside environment. Ethical Sensitivity is one of the individual factors that shape the student behavior. Students who have high ethical sensitivity can make wise decisions because they already have a strong ethical understanding. This implies that in the future accounting students should improve their Ethical Sensitivity so that the students can be more sensitive to the deviant behavior. The results of this study are supported by teleology theory which explains that there is a change in someone's behavior in taking an ethical or unethical decision.

The results of this study support the research of Febrianty (2010) which shows that ethical sensitivity affects the ethical behavior of accounting students. This study also supports the research of Al-Fithrie (2015) showing that Ethical Sensitivity has a positive and significant effect on the Ethical Perception of Accounting Students. In addition, research conducted by Yovita and Rahmawaty (2016) shows Ethical sensitivity has a significant effect on the ethical behavior of accounting students of Syiah Kuala University. In research conducted by Kusuma and Budisantosa (2017) states that Ethical sensitivity has a positive effect on the ethical behavior of auditors.

\section{Motivation Moderates the Effect of Moral Reasoning toward the Ethical Behavior}

Based on the results of the hypothesis testing, H3 is accepted, which means that motivation is able to modify the influence of moral reasoning on the ethical behavior of accounting students. Thus it can be concluded that the high motivation will influence the relationship between moral reasoning and ethical behavior. The results of this study are supported by attribution theory which explains that the actions taken by each individual are caused by attribution theory. This theory is to motivate a person to behave according to the situation he is facing. This shows that the level of moral reasoning that is owned by each student is influenced by motivation. Students who have high motivation, tend to have a high level of moral reasoning because students rely 
solely on feelings rather than logic. In addition, students who have low motivation tend to have low levels of moral reasoning because students only rely on logic without thinking with feelings.

Therefore, motivation produces a high or low level of moral reasoning and can affect the ethical behavior of accounting students. The results of this study are supported by research conducted by Suantara et al (2014) showing that the independence, professional expertise, and work experience of internal auditors have a positive and significant effect on the effectiveness of the internal control system with motivation as variable moderating. Research conducted by AlFithrie (2015) shows that Gender can moderate the relationship between moral reasoning and the ethical perception of accounting students.

\section{Motivation Moderates Ethical Sensitivity with the Ethical Behavior}

Based on the results of the hypothesis testing, H4 is accepted, which means that motivation is able to moderate ethical sensitivity with ethical behavior of accounting students. Thus it can be concluded that the high motivation will influence the relationship between ethical sensitivity and ethical behavior. The results of this study are supported by attribution theory which explains that the actions taken by each individual are caused by attribution theory. This theory is to motivate a person to behave according to the situation he is facing. This shows that the level of ethical sensitivity possessed by each student is influenced by motivation. Students who have high motivation tend to have a high level of ethical sensitivity because these students use feelings in thinking and doing more activities. In addition, students who have low motivation tend to have a low level of ethical sensitivity because these students use logic in thinking and doing activities.

Therefore, motivation produces a high or low level of moral reasoning and can affect the ethical behavior of accounting students. This study is consistent with research conducted by AlFithrie (2015) showing that Gender can moderate the relationship of Ethical Sensitivity to the Ethical Perception of Accounting Students. Research conducted by Suantara et al. (2014) shows that the independence, professional expertise, and work experience of internal auditors have a positive and significant effect on the effectiveness of the internal control system with motivation as moderating variable.

\section{CONCLUSION}

Based on the results of data analysis and discussion, it was concluded that moral reasoning affects the Ethical Behavior and Ethical Sensitivity of Accounting Students. Other results state 
that motivation is able to moderate the influence of Moral Reasoning on the ethical behavior of accounting students. Motivation is also able to moderate the influence of ethical sensitivity on the ethical behavior of accounting students. The suggestion for the next researcher is to be able to add research variables and also expand the respondents who are made into the population.

\section{REFERENCES}

Agoes, Sukrisno dan Cenik Ardana. 2009. Etika Bisnis dan Profesi Tantangan Membangun Manusia Seutuhnya. Jakarta: Salemba Empat.

Al-Fithrie, Nurul Luthfie. 2015. Pengaruh Moral Reasoning Dan Ethical Sensitivity Terhadap Persepsi Etis Mahasiswa Akuntansi Dengan Gender Sebagai Variabel Moderasi. Fakultas Ekonomi, Universitas Negeri Yogyakarta, Yogyakarta.

Brooks, Leonard J. dan Paul Dunn. 2011. Etika Bisnis \& Profesi, Untuk Direktur, Eksekutif, Dan Akuntan Edisi 5. Jakarta: Salemba Empat.

Febrianty. 2010. Pengaruh Gender, Locus Of Control, Intellectual Capital, Dan Ethical Sensitivity Terhadap Perilaku Etis Mahasiswa Akuntansi Pada Perguruan Tinggi. Jurnal Ilmiah Orasi Bisnis.

Fitri, Rachma. 2015. Pengaruh Emotional Intelligence, Gender, Intellectual Capital, Dan Ethical Sensitivity Terhadap Perilaku Etis Mahasiswa Akuntansi Universitas Muhammadiyah Sidoarjo Fakultas Ekonomi, Universitas Muhammadiyah Sidoarjo.

Gaffikin, Michael dan ASL Lindawati. 2012. The Moral Reasoning of Public Accountants in the Development of a Code of Ethics: the Case of or indoesia. Australasian Accounting, Business and Finance Journal. Vol 6 No 1.

Ghozali, Imam. 2005. Aplikasi Analisis Multivarat Dengan Program SPSS. Semarang: Badan Penerbit Universitas Diponegoro.

Haron, Hasnah, Ishak Ismail, dan Aw Lo Na. 2015. The Effect of Moral Reasoning, Exposure to Ethics and Perceived Ethical Climate on Ethical Judgement of Auditors in Malaysia. Asian Journal of Business and Accounting. Vol 8 No 2, pp 20 - 65.

Hasibuan, H. Malayu S.P. 2006. Manajemen Sumber Daya Manusia Edisi Revisi. Jakarta: Bumi Aksara.

Hermawan, Sigit dan Amirullah. 2016. Metode Penelitian Bisnis Pendekatan Kuantitatif dan Kualitatif. Malang: Media Nusa Creative. 
Hermiyetti, Meiliyah Ariani, dan Hernadewita. 2015. The Effect Of Moral Reasoning And The Student's Personal Factors Towards Student's Moral Behavior (Empirical Studies At Pancasila University, Jakarta). Scientific Journal of PPI-UKM.

Indrawijaya, Adam I. 2002. Perilaku Organisasi. Bandung: Sinar Baru Algensindo.

Irawan, Bambang. 2011. Analisis Sensitivitas Etis Mahasiswa Akuntansi Uin Suska Riau. Universitas Islam Negeri Sultan Sarif Kasim Riau.

Januarti, Indira dan Faisal. 2010. Pengaruh Moral Reasoning Dan Skeptisisme Profesional Auditor Pemerintah Terhadap Kualitas Audit Laporan Keuangan Pemerintah Daerah. Simposium Nasional Akuntansi XIII. Purwokerto.

Lubis, Arfan Ikhsan. 2014. Akuntansi Keperilakuan Edisi 2. Jakarta: Salemba Empat

Luthans, Fred. 2006. Perilaku Organisasi Edisi 10. Yogyakarta: Andi.

Kusuma, Ruth Novita Dani dan A.Totok Budisantosa. 2017. Analisis Pengaruh Equity Sensitivity Dan Ethical Sensitivity Terhadap Perilaku Etis Auditor. MODUS 29 (1):105-117

Mangkunegara, Anwar Prabu. 2005. Perilaku dan Budaya Organisasi. Bandung.

Nisa, Khoirun. 2016. Pengaruh Budgetary Goal Characteristics terhadap Kinerja Manajerial dengan Motivasi dan Komitmen Organisasi sebagai Variabel Moderating pada Perusahaan Kontraktor di Sidoarjo. Fakultas Ekonomi dan Bisnis, Universitas Muhammadiyah Sidoarjo, Sidoarjo.

Pamela, Astriana. 2014. Pengaruh Pemahaman Kode Etik Profesi Akuntan Terhadap Perilaku Etis Pada Mahasiswa Akuntansi Universitas Negeri Yogyakarta. Fakultas Ekonomi Universitas Negeri Yogyakarta, Yogyakarta.

Rachman, Eileen. 2006. Meraba Integritas, Bisakah? . Jakarta: Kompas Experd.

Risa, Nurma. 2011. Analisis Sensitivitas Etis Mahasiswa Universitas Islam '45 Bekasi. JRAK 1 (2):1-15.

Shamsuddin, Amanuddin., Fazliana Azzahara Bt Abd Wahab., Intan Athirah Binti Mohd Fu'ad., Khairunnisa Bt. Azis., dan Mohammad Adib Bin Mahmood. 2015. Factors That Influence The Ethical Sensitivity of Accounting Students in Malaysia Universities. Journal of Education and Social Science. Vol 2, pp 41 - 50.

Suantara, Gede, Lucy Sri Musmini dan Nyoman Trisna Herawati. 2014. Pengaruh Independensi, Keahlian Profesional Dan Pengalaman Kerja Auditor Internal Terhadap Efektivitas Sistem Pengendalian Internal Dengan Motivasi Sebagai Variabel Moderasi. e-Journal S1 Ak Universitas Pendidikan Ganesha 2 (1). 
Sugiyono. 2014. Metode Penelitian Kuantitatif, Kualitatif dan RAD. Bandung: Alfabeta.

Wibowo, Hardiyanto. 2002. Perbandingan Sensitivitas Etika Antara Mahasiswa Magister Akuntansi Pria Dan Mahasiswa Magister Akuntansi Wanita Serta Antara Mahasiswa Magister Akuntansi Dan Mahasiswa Magister Manajemen Di Jawa Tengah Dan DIY. Universitas Diponegoro Semarang.

Yovita, Cut Safira Dara dan Rahmawaty. 2016. Pengaruh Gender, Ethical Sensitivity, Locus Of Control, Dan Pemahaman Kode Etik Profesi Akuntan Terhadap Perilaku Etis Mahasiswa Akuntansi Universitas Syiah Kuala. Jurnal Ilmiah Mahasiswa Ekonomi Akuntansi (JIMEKA) 1 (2):252-263. 